\title{
1. Regulatory Autonomy and the Evolution of Australia's Participation in PTAs and BITs
}

\section{INTRODUCTION}

In just over 30 years, from 1983 through to 2015, Australia entered into 21 BITs and 10 PTAs. ${ }^{1}$ The enthusiasm of successive Australian governments for these bilateral and regional economic agreements continues, with the TPP having been signed by 12 Pacific-rim countries including the US, Japan, Chile and Malaysia in February 2016 (although the US has now withdrawn from that agreement) ${ }^{2}$ and more PTAs under negotiation. These include: the RCEP being negotiated among the ten ASEAN member States and those countries with PTAs with ASEAN (Australia, China, India, Japan, the Republic of Korea, and New Zealand); separate bilateral PTAs with India, Indonesia and the EU; the TiSA being negotiated outside the WTO to enhance liberalisation of trade in services among 23 WTO Members including the EU representing its 28 Member States (with negotiations led by the US, the EU and Australia); and the EGA being negotiated by representatives of 43 WTO Members to reduce tariffs on environmentally friendly goods. ${ }^{3}$ Yet both concluded agreements and ongoing negotiations have met with varying levels of controversy in Australia. Apart from the fear that bilateral and regional negotiations may distract from multilateral efforts to liberalise trade, one

1 See Tables 1.1, 1.2 and 1.3 below.

2 Letter from Maria L Pagan, Acting USTR, to the Trans-Pacific Partnership Depositary (30 January 2017).

3 See generally DFAT, Status of FTA Negotiations <http://dfat.gov.au/trade/ agreements/Pages/status-of-fta-negotiations.aspx $>$ (last visited 7 April 2017). DFAT announced on 24 April 2017 the commencement of negotiations with Hong Kong towards a PTA. 
of the major sources of concern has been the perceived threat posed by PTAs and BITs to Australia's sovereignty and 'regulatory autonomy'. ${ }^{4}$

In the context of international economic law, regulatory autonomy and policy space refer to the ability of a State to determine its regulatory goals (such as the protection of public health or the conservation of natural resources) and to adopt and implement policies to pursue those goals. Growing concerns about regulatory autonomy reflect a shift in the focus of international economic law, from overt barriers to trade (such as quotas on the importation of particular products, tariffs or customs duties imposed on imports as they cross the border, and trade remedies such as anti-dumping duties), to more subtle 'behind the border' measures that may reduce competitive opportunities for imports or infringe the rights of foreign investors. These measures may include registration or licensing requirements for service suppliers, health and safety standards for products, environmental standards applied to investments, and a vast range of other regulatory measures. For example, the PTA concluded between Australia and the US in 2004 (the AUSFTA) faced considerable backlash within the Australian community, centred on fears that the agreement could require significant changes to Australia's intellectual property laws, ${ }^{5}$ undermine public health initiatives (particularly access to affordable medicines through Australia's established system for subsidising pharmaceuticals: the PBS), ${ }^{6}$ and threaten policies promoting local media content. ${ }^{7}$

This book provides the first extended legal analysis of how Australia's current framework of PTAs and BITs affects Australia's regulatory autonomy. This analysis offers lessons for not only Australia but also other countries engaged in international trade and investment and attempting to improve the legal framework for these activities, including the 164 Members of the WTO and the 153 contracting States of the ICSID Convention. Investigating one country's treaties allows us to examine in depth the causes and implications of particular national part II.

4 The concept of 'regulatory autonomy' is defined more fully below in

5 Robert Burrell and Kimberlee Weatherall, 'Exporting Controversy? Reactions to the Copyright Provisions of the US-Australia Free Trade Agreement: Lessons for US Trade Policy' [2008] University of Illinois Journal of Law, Technology and Policy 259.

6 Evidence to JSCOT, Canberra (3 May 2004) (Dr Mukesh Haikerwal, Vice-President of the Australian Medical Association).

7 Ann Capling, All the Way with the USA: Australia, the US and Free Trade (University of New South Wales Press, 2005). 
strategies in trade and investment rather than drawing broad generalisations from the experiences of a wider range of countries. We focus on four key disciplines within Australia's PTAs and BITs-intellectual property rights, trade in services, standards for the protection of foreign investors, and their enforcement through ISDS-and then examine the impact of these agreements on regulating to protect the environment as a case study of a specific policy area. Before moving into this discussion, however, we need to locate Australia's PTAs and BITs in their political, social and economic context. This chapter provides this context.

In part II of this chapter we seek to define regulatory autonomy and its relationship with international economic law for the purposes of this book, turning in part III to offer further relevant background and details about the scope of agreements addressed and terminology used in this volume. We go on in parts IV to VI to analyse Australia's modern international economic agreements, which we group into three generations. The first and longest of these generations spans from the early 1980s through to the early 2000s, including almost all of Australia's BITs and its most deeply integrated PTA: the 1983 ANZCERTA. The second generation begins in 2003 with the conclusion of the SAFTA and includes many of Australia's PTAs and a few remaining BITs. The third generation of agreements are those concluded after 2010. In November 2010, the Australian Government's Productivity Commission issued an influential report evaluating the benefits of Australia's bilateral and regional trade agreements, covering both trade liberalisation and investment protection. Despite the reservations of the Productivity Commission about the benefits of PTAs, the conclusion of several significant PTAs after 2010 demonstrates the Australian government's continued interest in these agreements, although the content of these most recent treaties reflects greater public scrutiny and concern about the impact of international economic agreements on regulatory autonomy. Concluding in part VII of this chapter, we elaborate on the purpose and structure of the rest of the book.

\section{DEFINING 'REGULATORY AUTONOMY' AND ITS CONSTRAINTS}

\section{A The Development of International Economic Law as a Constraint on Autonomy}

Traditionally, the regulation of domestic industry and economic activity has been the prerogative of the State, governed primarily by domestic 
rather than international law. At its broadest level, regulatory autonomy may refer to the whole universe of areas in which a government might choose to act, whether for economic or non-economic objectives. Deciding to nationalise an industry, impose tariffs on particular imports, ban a carcinogenic substance, or impose environmental labelling standards would all fall within this broad notion of regulatory autonomy. Until the mid-20th century, the regulatory space available to States was 'almost unlimited'. 8

However, the very purpose of agreements regulating international trade or foreign investment, particularly as they began to emerge more prominently after World War II, was to constrain States' use of certain regulatory and policy tools, in order to pursue broader welfare objectives at national and international levels. The GATT 1947 restricted the use of various trade-related measures, including tariffs and non-tariff barriers such as 'quantitative restrictions' on imports. ${ }^{9}$ In addition to these rules targeting import restrictions, the GATT 1947 included more general obligations not to discriminate against imported products. These obligations extended to the use of internal taxes or charges, or any other 'laws, regulations and requirements affecting their internal sale, offering for sale, purchase, transportation, distribution or use'. ${ }^{10}$ In this way, the multilateral trade disciplines of the GATT regime began to impose constraints on States' use of measures that may not have appeared to be directly related to trade. Similarly, the BITs and other agreements relating to international investment that began to proliferate in the 1950s and 1960s imposed requirements on governments regarding a wide range of domestic regulatory and administrative actions. Given their historical context, in which capitalexporting States were seeking protection for their nationals investing in developing countries, these agreements were often designed to 'avoid under-inclusiveness' through the use of broadly framed obligations. ${ }^{11}$

To say that international economic law-as contained especially in the multilateral rules of the WTO (which entered into being in 1995 as the successor to the GATT 1947), and bilateral or regional PTAs and BITs-imposes limitations or constraints on regulatory autonomy is

8 Markus Wagner, 'Regulatory Space in International Trade Law and International Investment Law' (2014) 36(1) University of Pennsylvania Journal of International Law 1, 4.

9 See, eg, GATT 1947 arts II, XI.

10 GATT 1947 arts III:2, III:4. See also GATT 1947 art I:1.

11 Caroline Henckels, 'Protecting Regulatory Autonomy through Greater Precision in Investment Treaties: The TPP, CETA, and TTIP' (2016) 19(1) Journal of International Economic Law 27, 31-32. 
neither profound nor necessarily a criticism. It could be said that the very purpose of these agreements is to constrain regulatory autonomy, in order to prevent governments from acting in a 'protectionist' manner (that is, to protect their domestic industries) or infringing on the rights of foreign investors. As Natens says of multilateral or preferential agreements to liberalise trade:

As with all international obligations, this necessarily implies a loss of regulatory autonomy: by agreeing to be bound by certain obligations, a domestic regulator may no longer adopt regulations which violate these international obligations. ${ }^{12}$

Nevertheless, as the scope of domestic measures that may be subject to trade and investment rules has expanded, questions about the encroachment of international economic law into States' regulatory space have become both more frequent and more intense. Community concerns about these agreements have been particularly strong in relation to regulations that are not, on their face, concerned with international trade or foreign investment, instead pursuing some other public purpose.

In the early years of the GATT 1947, the GATT contracting parties retained significant regulatory autonomy, particularly with regard to elements of public welfare such as health, safety, and the natural environment. ${ }^{13}$ But with the gradual reduction of tariffs and quantitative restrictions on trade, focus shifted to measures enacted behind the border that affect the competitiveness of imports. Regulatory measures could be classified as 'non-tariff barriers' to trade on the basis of various criteria, such as their intent, their usual effect, or their legality under WTO rules. ${ }^{14}$ The difficulty with which international economic law has wrestled, particularly in more recent years (when explicit discrimination has become less commonplace), is distinguishing between legitimate regulatory measures and disguised acts of protectionism. Writing in the context of the WTO, Mattoo and Subramanian have noted:

The difficulty lies in distinguishing between two types of situations. In one situation, a non-protectionist government cannot prevent certain domestic policies from incidentally discriminating against foreign competitors; in the

12 Bregt Natens, Regulatory Autonomy and International Trade in Services (Edward Elgar, 2016) 4.

13 Wagner, above n 8, 4.

14 Roy Santana and Lee Ann Jackson, 'Identifying Non-Tariff Barriers: Evolution of Multilateral Instruments and Evidence from the Disputes (19482011)' (2012) 11(3) World Trade Review 462, 465. 
other, a protectionist government uses a legitimate objective as an excuse to design domestic policies which inhibit foreign competition. The challenge is to devise rules which are sensitive to the difference between these two situations, exonerating the former while preventing the latter. ${ }^{15}$

Although this passage was directed at the multilateral trading regime, its sentiment applies equally to the rules of PTAs and BITs. Discussing the impact of ISDS on regulatory autonomy, Broude, Haftel and Thompson have described the regulatory space available to States as a sort of continuum where:

at one extreme states have a great deal of flexibility to pursue policies they see fit, and are thus insulated from external pressure or influence attempts ... At the other extreme, governments have little room to maneuver and are highly constrained by the ability of foreign investors to challenge their policies under BITs and ISDS ... ${ }^{16}$

In referring in this book to 'regulatory autonomy' (which may also be called regulatory space, policy space, or perhaps even the 'right' to regulate), the aspect of that freedom with which we are primarily concerned is the ability of governments to take action for bona fide, non-economic public welfare purposes. To this extent, we view regulatory autonomy as a public good, which should be safeguarded in the design and implementation of PTAs and BITs. However, we note from the outset that absolute regulatory autonomy-allowing States virtually unfettered discretion to implement policies as they see fit-may be unhelpful in the international economic law context. Trade and investment agreements discipline domestic regulations, even those with an ostensible public purpose, due to 'concern that some useful forms of regulation may be viewed as discriminatory, or as unduly burdensome, or as effective barriers to market access' ${ }^{17}$ As the Australian Parliamentary committee JSCOT noted in its report on the TPP, the ISDS mechanism

15 Aaditya Mattoo and Arvind Subramanian, 'Regulatory Autonomy and Multilateral Disciplines: The Dilemma and a Possible Resolution' (1998) 1 Journal of International Economic Law 303, 303.

16 Tomer Broude, Alexander Thompson and Yoram Z Haftel, 'Who Cares About Regulatory Space in BITs? A Comparative International Approach' (SSRN Scholarly Paper ID 2773686, Social Science Research Network, 2 May 2016) 7, forthcoming in Anthea Roberts et al (eds), Comparative International Law (Oxford University Press).

17 Andrew TF Lang, 'The GATS and Regulatory Autonomy: A Case Study of Social Regulation of the Water Industry' (2004) 7(4) Journal of International Economic Law 801, 802. 
may open Australian regulatory measures to challenge, but if the Australian government fails in its defence of a measure, either the ISDS provisions are not functioning correctly or the measure is 'poor policy'. ${ }^{18}$ In this latter situation, JSCOT suggested that an investor should be entitled to compensation. ${ }^{19}$

\section{B International Economic Law: Impacts and Rationales}

When we discuss the potential for Australia's PTAs and BITs to constrain Australia's regulatory autonomy, we do not mean that they prevent the enactment or implementation of legislation or regulations, or the taking of certain administrative decisions. For Australia, PTAs, BITs and other treaties do not have direct effect in domestic law. Some legislation is usually necessary to comply with new trade obligations, for example to implement international commitments relating to tariffs, customs, intellectual property or other standards. ${ }^{20}$ However, the general obligations contained in the treaty do not automatically become part of domestic law.

The obligations contained in PTAs and BITs may nevertheless influence and limit Australia's policy choices as a result of domestic implementation of these norms and international compliance and enforcement mechanisms. Australia is also keen to be seen as a reliable economic partner in the international community, which affects how it applies laws and responds to even informal concerns raised about its compliance with international obligations. If an Australian measure is found inconsistent with WTO law in the WTO dispute settlement system, Australia needs to bring that measure into conformity with its WTO obligations, either immediately or within a 'reasonable period of time', ${ }^{21}$ or risk prospective retaliation in the form of 'suspension of concessions' (that is, non-compliance with WTO obligations) by the successful complainant WTO Member. ${ }^{22}$ Similarly, the State-to-State

\footnotetext{
18 JSCOT, Report 165: Trans-Pacific Partnership Agreement (November 2016) [6.46].

19 Ibid [6.47].

20 See, eg, US Free Trade Agreement Implementation Act 2004 (Cth).

21 DSU arts 21.1, 21.3.

22 DSU art 22.2. See generally Chad Bown and Joost Pauwelyn (eds), The Law, Economics and Politics of Retaliation in WTO Dispute Settlement (Cambridge University Press, 2010).
} 
dispute settlement mechanisms in Australia's PTAs and BITs ${ }^{23}$ could also require regulatory change, although in practice those mechanisms are not operative at present and are relatively rare in the broader international context as well. ${ }^{24}$

ISDS offers a more forceful means of enforcing investment obligations in many of Australia's PTAs and BITs, ${ }^{25}$ in which an investor may bring an investment treaty claim directly against the host State (whether that be Australia or Australia's treaty partner). In many contemporary investment agreements, the remedies available in ISDS proceedings are limited to monetary awards or restitution of property. ${ }^{26}$ Although claimants using provisions of older BITs may request an order that the host State withdraw the measures at issue, ${ }^{27}$ or seek specific performance or other satisfaction, such remedies are rarely awarded in ISDS. ${ }^{28}$ But it is not only a finding of liability and award of monetary compensation that may impact upon a State's regulatory decision-making. ISDS may be extremely costly for a host State in terms of both human resources and financial cost, even if the host State successfully defends its challenged measure. ISDS in particular may also create 'regulatory chill', causing a host State to hesitate before imposing more restrictive, intrusive or progressive regulatory measures 'even if not challenged in practice, or even if actual challenges are ultimately unsuccessful' ${ }^{29}$

To some extent, such hesitation may be appropriate. As noted above, PTAs and BITs, as well as international economic law more generally, are intended to prevent protectionist or discriminatory measures in order to pursue broader welfare goals. For example, the objectives of the WTO are recognised in the preamble to the Marrakesh Agreement that established the organisation:

23 See SAFTA ch 16; TAFTA ch 18; AUSFTA ch 21; ACIFTA ch 21; AANZFTA ch 17; MAFTA ch 20; KAFTA ch 20; JAEPA ch 19; ChAFTA ch 15; TPP ch 28.

24 But see Anthea Roberts, 'State-to-State Investment Treaty Arbitration: A Hybrid Theory of Interdependent Rights and Shared Interpretive Authority' (2014) 55(1) Harvard International Law Journal 1.

25 For a more detailed discussion of ISDS mechanisms included in Australia's PTAs and BITs, see Chapter 5.

26 See, eg, KAFTA art 11.26.1.

27 See, eg, Philip Morris v Australia, Jurisdictional Decision, [89].

28 Rudolf Dolzer and Christoph Schreuer, Principles of International Investment Law (Oxford University Press, 2nd ed, 2012) 293-294.

29 Broude et al, above n 16, 7. Cf JSCOT, Report 165, above n 18, [6.61]. 
Recognizing that their relations in the field of trade and economic endeavour should be conducted with a view to raising standards of living, ensuring full employment and a large and steadily growing volume of real income and effective demand, and expanding the production of and trade in goods and services, while allowing for the optimal use of the world's resources in accordance with the objective of sustainable development, seeking both to protect and preserve the environment and to enhance the means for doing so in a manner consistent with their respective needs and concerns at different levels of economic development.$^{30}$

Trade liberalisation (through 'the substantial reduction of tariffs and other barriers to trade and ... the elimination of discriminatory treatment in international trade relations') ${ }^{31}$ is a means towards these ends, as further noted in the preamble.

The causal connection between international trade liberalisation and national and global welfare gains ${ }^{32}$ is explained by the theory of comparative advantage, which is widely accepted in mainstream economics $^{33}$ and supported by empirical evidence of the impact of trade on poverty reduction in developing countries. ${ }^{34}$ However, the implementation of the theory in practice can be problematic, for example as regards the allowance of significant agricultural subsidies by WTO Members, ${ }^{35}$ the limitations of 'special and differential treatment' provided to developing countries, ${ }^{36}$ the inclusion of intellectual property as a

30 Marrakesh Agreement, preamble (italics in original; underlining added).

31 Marrakesh Agreement, preamble.

32 See, eg, Kym Anderson, 'Contributions of the GATT/WTO to Global Economic Welfare: Empirical Evidence' (2016) 30(1) Journal of Economic Surveys 56.

33 See, eg, Alan Sykes, 'Comparative Advantage and the Normative Economics of International Trade Policy' (1998) 1 Journal of International Economic Law 49.

34 See, eg, IMF, World Bank and WTO, Making Trade an Engine of Growth for All: The Case for Trade and for Policies to Facilitate Adjustment (2017) [84]; World Bank and WTO, The Role of Trade in Ending Poverty (2015).

35 See, eg, Kym Anderson and Will Martin, 'Agricultural Trade Reform and the Doha Development Agenda' (2005) 28(9) The World Economy 1301.

36 See, eg, Alexander Keck and Patrick Low, 'Special and Differential Treatment in the WTO: Why, When, and How?' in Simon Evenett and Bernard Hoekman (eds), Economic Development and Multilateral Trade Cooperation (World Bank, Palgrave Macmillan, 2006) 147. 
topic of international trade agreements at all, ${ }^{37}$ and, indeed, the impact of PTAs on the multilateral trading system. ${ }^{38}$

In addition to these challenges at the international level, domestically, countries need to deal with the 'adjustment costs' of trade liberalisation by providing financial or other forms of support such as retraining for industries and workers whose jobs may be lost as a result of trade. ${ }^{39}$ International trade agreements such as the WTO agreements and PTAs do not usually contain prescriptions regarding such matters, instead allowing each party to determine how best to redistribute the gains from trade in accordance with its own circumstances. A 2017 report by the WTO, IMF and World Bank notes that '[m]itigating adjustment costs' through domestic policies 'can help to alleviate resulting negative attitudes toward trade ... and make trade openness more socially sustainable'. ${ }^{40}$ The WTO Director-General Roberto Azevêdo has also noted that 'innovation, automation and new technologies are responsible for roughly $80 \%$ of the manufacturing jobs that have been lost'. ${ }^{41}$

The purpose of IIAs is typically understood as promoting or encouraging the flow of foreign direct investment into host States, by providing high standards of legal protection for the interests of investors, accompanied by an effective means of enforcement. For example, the preamble to the Australia-Mexico BIT states that the parties entered into the agreement:

Recognising the need to promote and protect foreign investments with the aim to foster their economic prosperity; ...

37 See, eg, Jayashree Watal, Intellectual Property Rights in the WTO and Developing Countries (Kluwer Law International, 2001).

38 See, eg, Richard Baldwin, 'Preferential Trading Arrangements' in Martin Daunton, Amrita Narlikar and Robert Stern, The Oxford Handbook on the World Trade Organization (Oxford University Press, 2012) 632; M Rafiqul Islam, 'The Australian Policy and Practice of Preferential Bilateral Trade: A Benign or Malign Alternative to the WTO Multilateral Free Trading System?' (2003) 2(2) Journal of International Trade Law \& Policy 43.

39 See, eg, Greg Thompson, Tim Murray and Patrick Jomini, 'Trade, Employment and Structural Change: The Australian Experience' in Douglas Lippoldt (ed), Policy Priorities for International Trade and Jobs (OECD, 2012) 113. See also Alan Winters, 'International Trade Regulation and Job Creation' (September 2014) World of Labor (online).

40 IMF, World Bank and WTO, above n 34, [44].

41 WTO, 'Trade Recovery Expected in 2017 and 2018, Amid Policy Uncertainty', Press/793. Trade Statistics and Outlook (12 April 2017). 
Intending to create and maintain favourable conditions for investments by Investors of one Contracting Party in the territory of the other Contracting Party; and

Recognising that pursuit of these objectives would be facilitated by a clear statement of principles relating to the protection of investments, combined with rules designed to render more effective the application of these principles within the territories of the Contracting Parties; ${ }^{42}$

Providing legal protections for foreign investors is beneficial to host States, at least in theory, as they receive the benefits of increased foreign investment. ${ }^{43}$ However, debate exists as to whether the conclusion of IIAs or the availability of ISDS under those treaties does, in fact, promote or encourage foreign investment. ${ }^{44}$

From the perspective of capital-exporting States, BITs provide their nationals with greater protection when investing in foreign countries, and ISDS mechanisms allow the enforcement of these protections without the need for the home State to exercise any rights of diplomatic protection. ${ }^{45}$ In this way, BITs have also been described as a means of depoliticising investment disputes and avoiding so-called 'gunboat diplomacy'. ${ }^{46}$ The availability of a formal means of resolving investment disputes may be particularly important for investment in countries with unstable political systems or under-developed judicial systems.

42 Emphasis added.

43 On the impact of foreign investment on the economic development of recipient states, see: Olivier de Schutter et al (eds), Foreign Direct Investment and Human Development (Routledge, 2013); Jonathan Bonnitcha, 'Foreign Investment, Development and Governance: What International Investment Law Can Learn from the Empirical Literature on Investment' (2016) 7 Journal of International Dispute Settlement 31.

44 See generally Karl Sauvant and Lisa Sachs (eds), The Effect of Treaties on Foreign Direct Investment (Oxford University Press, 2009); Jason Webb Yackee, 'Do BITs "Work"? Empirical Evidence from France' (2016) 7 Journal of International Dispute Settlement 55; Thomas Schultz and Cédric Dupont, 'Investment Arbitration: Promoting the Rule of Law or Over-Empowering Investors? A Quantitative Empirical Study' (2014) 25 European Journal of International Law 1147.

45 On the difficulties of diplomatic protection or 'espousal' as a means of enforcing investor rights, see Kenneth J Vandevelde, "A Brief History of International Investment Agreements' (2005) 12 UC Davis Journal of International Law \& Policy 157, 160.

46 Stephen M Schwebel, 'In Defense of Bilateral Investment Treaties' (2015) 31 Arbitration International 181, 182. 
However, IIAs generally contain reciprocal obligations and benefits, protecting both inward and outward investment with respect to each State party. Developed and developing countries alike have increasingly realised that ISDS represents a potentially intrusive form of dispute settlement that may be used by an investor of either party. Concerns about international investment law in general and ISDS in particular have mounted in more recent years especially because of factors such as the absence of a centralised appellate mechanism, the unpredictability of the reasoning and outcomes of investment treaty arbitrations, the potential for conflicts of interest in the overlap between arbitrators and counsel, the targeting of regulatory measures with a range of policy goals, and the size of monetary awards. ${ }^{47}$ These kinds of concerns have led to some States terminating BITs, withdrawing from the ICSID Convention ${ }^{48}$ (which provides the framework for many ISDS proceedings), or re-evaluating their approaches to ISDS, as in the case of Australia as discussed further below.

In discussing Pakistan's BITs as an example of developing country approaches to international investment law, Poulsen writes:

BITs had merely been considered a diplomatic token of goodwill. There was an expectation that the treaties would lead to increased inflows of foreign investment, something Pakistan desperately needed, but they were not thought to have any liabilities or regulatory constraints ... It was ... not until Pakistan was hit by a multimillion-dollar arbitration claim that officials realized the implications of treaties signed by shifting governments since 1959.49

From a behavioural perspective, Poulsen explains the acceptance by many developing countries of the 'modern investment treaty regime' as arising from 'bounded rationality': 'policy-makers are subject to cognitive constraints and often prone to make mistakes', suffering from

47 See, eg, Gus van Harten, 'Perceived Bias in Investment Treaty Arbitration' in Michael Waibel et al (eds), The Backlash Against Investment Arbitration (Kluwer Law International, 2010) 433; M Sornarajah, 'The Case Against a Regime on International Investment Law' in Leon E Trakman and Nicola W Ranieri (eds), Regionalism in International Investment Law (Oxford University Press, 2013) 475; UNCTAD, Investor-State Dispute Settlement: Review of Developments in 2014 (IIA Issues Note No 2, May 2015) 5.

48 See the examples of termination and withdrawal in Tania Voon and Andrew D Mitchell, 'Denunciation, Termination and Survival: The Interplay of Treaty Law and International Investment Law' (2016) 31(2) ICSID Review 413.

49 Lauge N Skovgaard Poulsen, Bounded Rationality and Economic Diplomacy: The Politics of Investment Treaties in Developing Countries (Cambridge University Press, 2015) xv. 
'systematic information processing biases' rather than engaging in 'sophisticated cost-benefit calculations'. ${ }^{50} \mathrm{He}$ suggests that a preference for the status quo may also explain why the growing awareness among developing countries of the unexpected costs of ISDS has not led to wholesale reform and renegotiation of their investment treaties. ${ }^{51}$ On the contrary, the 'motivated optimism that resulted in a rush to sign BITs during the 1990s seems to be repeating itself with investment chapters in PTAs'.52

Poulsen also notes that developed countries that have themselves been challenged under ISDS may be more open to pursuing major reforms in international investment law. ${ }^{53}$ Australia falls in that category, having now successfully defended its first ISDS claim (brought by Philip Morris Asia Ltd against Australia's world-first 'plain' tobacco packaging scheme, as elaborated in Chapter 2). As Australia awaits the outcome of multiple complaints against the same scheme in the WTO (also addressed in Chapter 2), and in view of the US withdrawal from the TPP and ongoing changes to the landscape of international economic law flowing from the election of President Donald Trump, now is an appropriate time to reflect on Australia's engagement with international economic law through its PTAs and BITs. With full understanding of the potential for international trade and investment disputes to constrain regulatory decision-making, and of the possibility that unexpected developments such as Brexit and the US election will have lasting impacts on international institutions and the global economy, Australia has the opportunity to evaluate its past treaty practice and make improvements for the future.

\section{IDENTIFYING AUSTRALIA'S PTAs AND BITs: HISTORY, SCOPE AND TERMINOLOGY}

Australia's PTAs and BITs may pursue public policy objectives beyond narrow goals of liberalising trade and promoting inward and outward investment, which may explain why Australia's approaches to these agreements have changed over time. The intention of this chapter is not to provide a comprehensive history of Australia's trade and investment

\footnotetext{
50 Ibid 17.

51 Ibid 200, 203.

52 Ibid 197.

53 Ibid 200.
} 
policies, or of the nation's participation in international economic agreements. ${ }^{54}$ Instead, we are concerned with exploring the origins and context of the PTAs and BITs that currently influence Australia's regulatory autonomy, laying the foundation for the discussion of specific disciplines contained in these treaties in the chapters that follow. For this reason, our detailed examination begins with ANZCERTA, the PTA concluded between Australia and New Zealand in 1983 (which, as discussed below, has evolved considerably over time).

However, ANZCERTA was not Australia's first bilateral economic agreement. Australia had entered several earlier bilateral agreements, ${ }^{55}$ the most significant being with the United Kingdom ${ }^{56}$ and Japan. ${ }^{57}$ These agreements were, however, quite different from the more modern PTAs discussed in this book. Many of these agreements, including 11 treaties that Australia concluded rapidly between 1972 and 1975, were intended to "provide a peg for governmental discussion and development of

54 For more detailed accounts of this history, see John Crawford, Nancy Anderson and Margery GN Morris, Australian Trade Policy, 1942-1966: A Documentary History (Australian National University Press, 1968); Richard H Snape, Lisa Gropp and Tas Luttrell, Australian Trade Policy, 1965-1997: A Documentary History (Allen \& Unwin, 1998); Richard WT Pomfret (ed), Australia's Trade Policies (Oxford University Press, 1995); David Meredith and Barrie Dyster, Australia in the Global Economy: Continuity and Change (Cambridge University Press, 2nd ed, 2012); Ann Capling, Australia and the Global Trade System: From Havana to Seattle (Cambridge University Press, 2001).

55 See, eg, Trade Agreement between Australia and Canada, signed 8 July 1931, [1931] ATS 1 (entered into force 3 August 1931); Trade Agreement between the Governments of the Commonwealth of Australia and the Federation of Rhodesia and Nyasaland, signed 30 June 1955, [1955] ATS 10 (entered into force 6 July 1955); Trade Agreement between the Government of the Commonwealth of Australia and the Government of the Republic of the Philippines, and Agreed Minutes, signed 16 June 1965, [1965] ATS 7 (entered into force 16 June 1965).

56 See, eg, Trade Agreement between Australia and the United Kingdom of Great Britain and Northern Ireland, signed 20 August 1932, [1932] ATS 16 (entered into force 20 August 1932); United Kingdom-Australia Trade Agreement, signed 26 February 1957, [1957] ATS 2 (entered into force 9 November 1956).

57 See, eg, Agreement on Commerce between the Commonwealth of Australia and Japan, and Four Exchanges of Notes, signed 6 July 1957, [1957] ATS 15 (entered into force 4 December 1957); Basic Treaty of Friendship and Co-operation between Australia and Japan, and Protocol, signed 16 June 1976, [1977] ATS 19 (entered into force 20 August 1977). See also Meredith and Dyster, above n 54, 225. 
commercial relations'. ${ }^{58}$ In other words, these agreements were intended to provide a starting point for the deepening of trade and economic relations, without making much substantive progress towards that goal. The coverage and scope of trade liberalisation commitments and investor protections in Australia's early bilateral trade agreements was very limited. For example, the 1957 trade agreement with the United Kingdom focussed on tariff preferences for only a small range of scheduled products, rendering its coverage far narrower than modern PTAs. ${ }^{59}$ Similarly, in 1976 Australia concluded a general economic treaty with Japan that included investor protections, but these were limited in scope, covering only full protection and security, FET and MFN treatment obligations, and with no mechanism for enforcement. 60 Although this treaty was the 'first of its kind that Australia had concluded with any country', 61 it bears little resemblance to the more comprehensive BITs that Australia began to conclude from 1988 onwards.

Australia's first modern PTA (ANZCERTA) came in the 1980s, reflecting broader reforms in economic policy and trends towards liberalisation. For the first half of the 20th century, through to the 1970s, Australia had maintained a relatively high degree of protection of its domestic industry, particularly in manufacturing. ${ }^{62}$ Protectionist policies were seen as necessary for nation-building in Australia-which was still economically developing and highly reliant on commodities/ agriculture-and to provide employment for a growing population. ${ }^{63}$ Although Australia was a party to the GATT from 1947 and involved in multilateral trade negotiations, it did not 'participate to any significant extent' in the negotiated tariff reductions of the Kennedy and Tokyo

58 R Burnett, 'Australia's Bilateral Trade Treaties-Developments 19721975' (1974) 6 Australian Yearbook of International Law 153, 157.

59 United Kingdom-Australia Trade Agreement, signed 26 February 1957, [1957] ATS 2 (entered into force 9 November 1956) sch A.

60 Basic Treaty of Friendship and Co-operation between Australia and Japan, and Protocol, signed 16 June 1976, [1977] ATS 19 (entered into force 20 August 1977) arts IX.1, IX.2.

61 Moreen Dee, Friendship and Co-operation: The 1976 Basic Treaty between Australia and Japan (DFAT, 2006) 44.

62 Jonathan Pincus, 'Evolution and Political Economy of Australian Trade Policies' in Pomfret, Trade Policies, above n 54, 53.

63 These Australian policies can be compared to the Canadian approach to international trade relations, given that country's relatively similar economic profile. See Richard Pomfret, 'Trade Policy in Canada and Australia in the Twentieth Century' (2000) 40 Australian Economic History Review 114. 
Rounds of GATT negotiations. ${ }^{64}$ Australia did not make international commitments for significant tariff cuts until the Uruguay Round of GATT negotiations, and, at that same time, it began to engage in unilateral trade liberalisation, such as phased cuts announced in $1988 .{ }^{65}$

After the conclusion of ANZCERTA in 1983, Australia continued to enter into trade agreements that we do not classify as PTAs for the purposes of this book. ${ }^{66}$ Like many of the earlier trade agreements, these bilateral treaties were often aspirational agreements to explore future opportunities to promote trade, rather than comprehensive agreements to lower barriers to trade. ${ }^{67}$ Although these agreements vary significantly, the PTAs we examine in this book are detailed and relatively comprehensive trade agreements, covering a range of disciplines relating to trade in both goods and services. ${ }^{6}$ The BITs that we examine include the core obligations that have become synonymous with modern international investment law, such as provisions on expropriation and FET (see Chapter 4); most also provide for enforcement through ISDS (see Chapter 5). We use the term BIT to refer to bilateral agreements that relate exclusively to investment, regardless of the nomenclature used in the official title of the agreement. ${ }^{69}$ In addition to BITs, investment obligations are also included as a specific chapter of some PTAs. We use the term international investment agreement or IIA to refer collectively to BITs and PTAs containing investment obligations.

64 Snape, Gropp and Luttrell, above n 54, 363.

65 Ibid.

66 See, eg, Trade Agreement between the Government of Australia and the Government of the Federal Republic of Nigeria, signed 6 August 1989, [1989] ATS 20 (entered into force 6 August 1989); Trade Agreement between the Government of Australia and the Government of the Islamic Republic of Pakistan, signed 12 July 1990, [1990] ATS 24 (entered into force 12 July 1990).

67 See, eg, Agreement on Economic Cooperation between the Government of Australia and the Government of the Kingdom of Thailand, signed 6 August 1990, [1990] ATS 29 (entered into force 6 August 1990) arts II, III.

68 Essentially, these agreements would at least purport to be consistent with the requirements for PTAs established by GATT 1994 art XXIV(8)(b) and GATS art $\mathrm{V}(1)$, meaning that they eliminate duties or other restrictions on substantially all trade between the constituent territories of the free trade area. In Chapters 2 and 3 we offer some thoughts on these requirements in the context of intellectual property and services respectively.

69 Most of Australia's BITs are titled agreements 'for the Promotion and Protection of Investments'. See, eg, Australia-Pakistan BIT; Australia-Lao PDR BIT; Australia-Czech Republic BIT. 


\section{FIRST GENERATION: ANZCERTA AND BITs}

The first generation of Australia's PTAs and BITs, as defined in this book, includes the largest number of agreements, as set out in Table 1.1.

\section{Table 1.1 Australia's 'First Generation' BITs and PTAs in Order of Signature}

\begin{tabular}{ll}
\hline Year of signature & Agreement \\
\hline 1983 & ANZCERTA \\
1988 & Australia-China BIT \\
1990 & Australia-Papua New Guinea BIT \\
1991 & Australia-Viet Nam BIT \\
1991 & Australia-Poland BIT \\
1991 & Australia-Hungary BIT \\
1992 & Australia-Indonesia BIT \\
1993 & Australia-Romania BIT \\
1993 & Australia-Hong Kong BIT \\
1993 & Australia-Czech Republic BIT \\
1994 & Australia-Lao PDR BIT \\
1995 & Australia-Argentina BIT \\
1995 & Australia-Peru BIT \\
1995 & Australia-Philippines BIT \\
1996 & Australia-Chile BIT \\
1998 & Australia-Pakistan BIT \\
1998 & Australia-Lithuania BIT \\
1999 & Australia-India BIT \\
2001 & Australia-Egypt BIT \\
2001 & Australia-Uruguay BIT \\
\hline & Australia-Sri Lanka BIT \\
\hline
\end{tabular}

As this table illustrates, all of the agreements in this 'first generation' are BITs, with the exception of ANZCERTA. Given the unique timing and content of ANZCERTA we consider it first, before turning to discuss Australia's program of negotiating BITs. 


\section{A International Trade Agreements: ANZCERTA as an Exception to the Multilateral Focus}

ANZCERTA was the first of Australia's modern bilateral trade agreements, but its predecessors date back to the 1920s. ${ }^{70}$ ANZCERTA replaced the 1965 New Zealand-Australia Free Trade Agreement, which had removed 80 per cent of the tariffs on trade between the two countries by the late $1970 \mathrm{~s},{ }^{71}$ leaving some significant barriers still in place. Tariff reductions applied only to scheduled goods, and the agreement lacked any mechanism for compulsorily removing the remaining restrictions. ${ }^{72}$ Other barriers to trade that were not removed by the 1965 agreement included significant quantitative restrictions (such as Australia's unwillingness to open much of its dairy market to products from New Zealand) and export incentives. ${ }^{73}$ Agreement to promote further growth in trade between the two countries provided the impetus for negotiation of a new agreement to create a 'closer economic relationship'. ${ }^{74}$

What has made the ANZCERTA so significant, beyond it simply being Australia's first modern PTA, was the depth of integration that the parties have achieved through the evolution of the agreement. ANZCERTA did not immediately liberalise or remove all barriers to trade between Australia and New Zealand: '[i]n its initial form ... ANZCERTA was a cautious, even timid agreement.' 75 In the late 1970s and early 1980s, politicians from the two countries discussed a range of models for promoting wider economic cooperation, including an extension of the

70 These included: Trade Agreement between Australia and New Zealand, signed 11 April 1922, [1922] ATS 5 (entered into force 1 September 1922); Trade Agreement between the Commonwealth of Australia and the Dominion of New Zealand, signed 5 September 1933, [1933] ATS 14 (entered into force 1 December 1933); New Zealand-Australia Free Trade Agreement, signed 31 August 1965, [1966] ATS 1 (entered into force 1 January 1966).

71 DFAT, Closer Economic Relations: Background Guide to the Australia New Zealand Economic Relationship (DFAT, February 1997) 6.

72 Ibid.

73 Meredith Kolsky Lewis, 'The Politics and Indirect Effects of Asymmetrical Bargaining Power in Free Trade Agreements' in Tomer Broude, Marc L Busch and Amelia Porges (eds), The Politics of International Economic Law (Cambridge University Press, 2011) 19, 26.

74 See communiqué issued by Prime Ministers Fraser and Muldoon, Wellington, New Zealand (21 March 1980).

75 Robert Scollay, Christopher C Findlay and Uwe Kaufmann, Australia New Zealand Closer Economic Relations Trade Agreement (ANZCERTA) and Regional Integration (Institute of Southeast Asian Studies, 2011) 22. 
limited free trade area set up by the 1965 agreement, a full free trade area, a customs union, an economic community, or a monetary union. ${ }^{76}$ The decision not to pursue a customs union or other closer form of integration was in part due to significant differences in the tariff structures of the two countries at the time, ${ }^{77}$ as well as Australian concerns that the adoption of a common external tariff would necessitate an increase over current Australian levels, in turn 'encourag[ing] the expansion of industries which are inefficient by world standards'. ${ }^{78}$

Despite these limitations of the original ANZCERTA, this treaty has provided the framework for what is now a highly integrated TransTasman market. By mid-1990, all tariffs and quantitative restrictions had been lifted on trade between Australia and New Zealand, as a result of the 1988 ANZCERTA Protocol on Acceleration of Free Trade in Goods: five years ahead of the schedule originally agreed in $1983 .{ }^{79}$ Although the initial treaty did not include trade in services or protection of foreign investment, disciplines on these topics were added through subsequent protocols agreed in 1988 and 2011 respectively. ${ }^{80}$ Another significant feature of the current ANZCERTA relationship is the mutual recognition arrangements that have been created for many product standards, food standards, and qualifications in professional services, which remain unrivalled in any of Australia's other PTAs. ${ }^{81}$ ANZCERTA has also

76 Lusaka Agreement, 'Prime Minister's Meeting with Mr Muldoon' (6 August 1979) [7], document 20 in Pamela Andre, Stephen Payton and John Mills (eds), The Negotiation of the Australia New Zealand Closer Economic Relations Trade Agreement 1983 (DFAT and New Zealand Minister of Foreign Affairs and Trade, 2003).

77 Scollay, Findlay and Kaufmann, above n 75, 23.

78 See Department of the Treasury, Commonwealth of Australia, 'Closer Economic Integration between Australia and New Zealand-Possible Impact on the Australian Economy' (October 1979), document 34 in Andre, Payton and Mills, above n 76 .

79 ANZCERTA Protocol on Acceleration of Free Trade in Goods. See also DFAT, above $n$ 71, 6 .

80 ANZCERTA Services Protocol; ANZCERTA Investment Protocol.

81 See generally Council of Australian Governments, The Trans-Tasman Mutual Recognition Arrangement, <https://www.coag.gov.au/about-coag/ agreements/trans-tasman-mutual-recognition-arrangement-arrangement-betweenaustralian> (last visited 7 April 2017); Food Standards Australia and New Zealand, About FSANZ, <http://www.foodstandards.gov.au> (last visited 7 April 2017); Lewis, above n 73, 26; Debra P Steger, 'Institutions for Regulatory Cooperation in "New Generation” Economic and Trade Agreements' (2012) 39 Legal Issues of Economic Integration 109, 115. 
facilitated cooperation in other fields, including harmonisation of business law and reducing discrimination in government procurement. ${ }^{82}$

At the time of ANZCERTA, Australian politicians had little desire to seek similarly deep or comprehensive economic agreements with other trading partners. In a statement to the GATT Ministerial Meeting in 1982, then Deputy Prime Minister and Minister for Trade and Resources, Doug Anthony, linked bilateral trade agreements with protectionism, arguing:

This resort to solving one's problems at the expense of one's trading partners or of seeking bilateral solutions outside the multilateral framework put very great pressure on all of us, especially the smaller trading nations. ${ }^{83}$

Many of Australia's key aims in international trade diplomacy at the time centred around improving access to markets in major industrialised countries for its agricultural exports and commodities-difficult goals that most expected would be more achievable through multilateral negotiations. ${ }^{84}$ As Frederick Abbott and others have argued, relatively small or weak nations have greater power in multilateral negotiations, as they can band together to resist pressure from major economic powers such as the US or the EU. ${ }^{85}$ In 1986, the Department of Trade and Economic Planning Advisory Council considered whether or not Australia should pursue a bilateral trade agreement with the US, but concluded that it would be preferable for Australia to lower its tariff barriers unilaterally, and that multilateral or large regional efforts to liberalise were preferable to bilateral initiatives. ${ }^{86}$

Thus, the ANZCERTA was something of an anomaly, and the parties sought to ensure that it would 'be designed to enhance relationships with

82 See Memorandum of Understanding Between the Government of New Zealand and the Government of Australia on the Coordination of Business Law (2010); Australian and New Zealand Government Procurement Agreement (revised September 2013).

83 'Australia's Opening Statement to the GATT Ministerial Meeting', document 9:15 in Snape, Gropp and Luttrell, above n 54, 406.

84 See generally Richard H Snape, Jan Adams and David Morgan, Regional Trade Agreements: Implications and Options for Australia (Australian Government Printing Service, 1993).

85 Frederick M Abbott, 'A New Dominant Trade Species Emerges: Is Bilateralism a Threat?' (2007) 10 Journal of International Economic Law 571.

86 'Should Australia Seek US Trade Preferences', document 10:1 in Snape, Gropp and Luttrell, above n 54, 471. 
third countries', rather than being inward-looking. ${ }^{87}$ The conclusion and evolution of ANZCERTA reflects the close political relationship between Australia and New Zealand, as much as their economic connection. Neither country has been 'the most important trading partner of the other', particularly since historically both States have had a similar focus on commodity exports and agricultural production. ${ }^{88}$ The Australian negotiators in the early stages of talks noted that the economic gains on offer from an agreement were likely to be small. ${ }^{89}$ In many respects, ANZCERTA has been driven by the unique 'deep ties of common origin and shared ideals and institutions which give a sound basis for the closest co-operation' ${ }^{90}$

Unsurprisingly given the close historical relationship of Australia and New Zealand, as well as their economic and cultural similarities, we have found no evidence that the conclusion of ANZCERTA was seen as a threat to regulatory autonomy. During the 1980s, international trade law was still largely concerned with tariffs and more obvious non-tariff barriers to trade, rather than regulatory measures. ${ }^{91}$ As a result, concerns about regulatory autonomy were not widespread at this time. Moreover, to the extent that harmonisation of standards was discussed in the ANZCERTA negotiations, Australia was unlikely to be concerned that this would threaten its regulatory space. As the larger economy, Australia may have presumed that any harmonised standards would likely be based on existing Australian approaches. ${ }^{92}$ As explained below, this presumption did not hold for later PTAs, such as the AUSFTA. ${ }^{93}$

87 Statement of Understanding, 'Australian-New Zealand Economic Co-operation-Statement of Understanding between Permanent Heads', Canberra (3 November 1979), document 52 in Andre, Payton and Mills, above n 76.

88 Ian McLean, 'Trans-Tasman Trade Relations: Decline and Rise' in Pomfret, Trade Policies, above n 54, 171, 171.

89 See Department of the Treasury, Commonwealth of Australia, 'Closer Economic Integration between Australia and New Zealand-Possible Impact on the Australian Economy' (October 1979), document 34 in Andre, Payton and Mills, above n 76 .

90 Nareen Statement, 'Joint Statement of the Prime Minister of Australia Malcolm Fraser and the Deputy Prime Minister of New Zealand Brian Talboys' (20 March 1978), document 1 in Andre, Payton and Mills, above n 76.

91 This concern began to emerge more prominently in the late 1990s, as discussed in part $\mathrm{V}$ below.

92 Lewis, above n 73, 27.

93 See part V below. 


\section{B International Investment Agreements: Australia as a Relative Latecomer}

It was not until the late 1980s, several years after ANZCERTA was signed, that Australia began concluding BITs and other IIAs. The first of these agreements was with China in $1988,{ }^{94}$ as part of an ongoing process of encouraging bilateral trade and economic relations. ${ }^{95}$ Australia was a rather late arrival to the world of BITs, compared to other highly industrialised nations. Many European countries had begun to seek specific agreements for the protection of their foreign investors in the 1950s and 1960s, with the 1959 Germany-Pakistan BIT often cited as the first modern BIT. The US started entering BITs from the early 1980s, ${ }^{96}$ although it had concluded 20 Friendship, Commerce and Navigation treaties that included at least some protections for foreign investors between 1945 and $1966 .{ }^{97}$ Canada, which had similar economic interests and priorities to Australia throughout much of the 20th century, ${ }^{98}$ did not begin negotiating BITs until 1989.99 Once Australia had begun its program of entering into BITs, it did so enthusiastically, concluding 19 agreements between 1988 and 2002.100 Australia's embrace of BITs in the 1990s mirrored a wider international trend: during this decade up to 200 such agreements were concluded globally each year. ${ }^{101}$ The increasing acceptance of investment protection norms in bilateral treaties sparked efforts to create a multilateral framework through the OECD in the mid-late 1990s. Consistent with its approach to international trade policy, Australia was an active participant in the OECD's efforts to create

94 Australia-China BIT.

95 Snape, Gropp and Luttrell, above n 54, 466.

96 See, eg, Treaty Between the United States of America and the Republic of Panama Concerning the Treatment and Protection of Investments, signed 27 October 1982 (entered into force 30 May 1991); Treaty Between the United States of America and the Republic of Senegal Concerning the Reciprocal Encouragement and Protection of Investment, signed 6 December 1983 (entered into force 25 October 1990).

97 Vandevelde, above n 45, 162.

98 See generally Pomfret, above n 54.

99 Agreement between the Government of Canada and the Government of the Union of Soviet Socialist Republics for the Promotion and Reciprocal Protection of Investments, signed 20 November 1989 (entered into force 27 June 1991).

100 See Table 1.1.

101 UNCTAD, 'Recent Trends in IIAs and ISDS', IIA Issues Note No 1 (February 2015) 2. 
a multilateral agreement on investment (MAI), ${ }^{102}$ although these efforts ultimately failed. ${ }^{103}$

Unfortunately, few publicly available documents directly explain why Australia began to seek out BITs in the late 1980s and throughout the 1990s. A joint communiqué issued by federal, state and territory governments in Australia in 1991 called for 'coordinated action programs to pursue bilateral trade and investment strategies for priority interests', ${ }^{104}$ without explicitly mentioning treaty negotiation. The welcoming of foreign investment in the late 1980s and 1990s was in sharp contrast to investment policy espoused by Australia in the 1970s, which could almost have been described as an environment of overt hostility: "political opinion in Australia was running strongly in favour of curbing the role of foreign direct investment'. ${ }^{105}$ The enactment of the Companies (Foreign Take-overs) Act of 1972 (Cth) was the first legislative step taken by the Australian government to enable regulation of foreign investment (beyond the use of foreign exchange controls) ${ }^{106}$ and a precursor to the Foreign Acquisitions and Takeovers Act 1975 (Cth), which regulated take-overs of companies as well as certain purchases of real assets. ${ }^{107}$ Australia resisted pressure throughout the 1970s from some members of ASEAN to enter into agreements for the protection and promotion of investment. ${ }^{108}$

The conclusion of BITs - reciprocal agreements designed to encourage and protect foreign investments-in the late 1980s and 1990s represented a major shift towards liberalisation in Australia's policy, although controls on and oversight of inbound foreign investment remained. A major factor behind Australia's move towards BITs in the late 1980s is likely to have been the increase in outward foreign investment from Australia. For

102 See JSCOT, Report 18: Multilateral Agreement on Investment: Final Report (March 1999).

103 See Rainer Geiger, 'Multilateral Approaches to Investment: The Way Forward' in José E Alvarez et al (eds), The Evolving International Investment Regime (Oxford University Press, 2011) 153, 157-160.

104 Towards a National Trade Strategy, Joint communiqué by Commonwealth, state and territory ministers with responsibilities for international trade and business development (28 November 1991).

105 Meredith and Dyster, above n 54, 214.

106 See Snape, Gropp and Luttrell, above n 54, 666-667.

107 At the time of writing, this Act is still in force and continues to provide the legislative framework for Australia's foreign investment policy, although it has been amended several times since 1975 .

108 Palitha TB Kohona, 'Investment Protection Agreements: An Australian Perspective' (1987) 21 Journal of World Trade 79, 87. 
most of the 20th century, Australia was largely a recipient of foreign capital and investment.109 By the 1980s, however, more Australian companies were investing in other countries, particularly in Asia, creating an incentive for the government to negotiate treaties to ensure protection of their rights. ${ }^{110}$ In addition, the general liberalisation of the Australian economy in the 1970s and 1980s, which included relaxing controls on foreign investment, diminished concerns that entering into BITs would undermine the ability of the Australian government to regulate the entry of foreign investment. ${ }^{111}$

The countries with which Australia entered BITs during this period did not follow any obvious geographic pattern. Several Eastern European countries were included in the program, such as Hungary, Poland, Romania, and the Czech Republic. ${ }^{112}$ Negotiating with these States was part of a broader strategy of seeking access to markets and economic opportunities in formerly Communist countries, particularly following the collapse of the Eastern Bloc. ${ }^{113}$ These historic events were viewed as opening up 'potentially significant opportunities' for Australian companies to invest in Eastern Europe. ${ }^{114}$ Australia also entered BITs with neighbours in Asia-including China, Indonesia, Laos, the Philippines, and Viet Nam-and with a number of South American countries, including Argentina, Uruguay, and Peru. ${ }^{115}$ Although Australia had recognised the importance of markets in Asia for some time, the country was only beginning to recognise the potential for investment and trade with Latin American States by the 1990s. ${ }^{116}$ In particular, investment by major mining companies in Latin America was cited as a basis for entering into these BITs. ${ }^{117}$ Thus, while possible motivations for entering

$\begin{array}{ll}109 & \text { Ibid } 67 . \\ 110 & \text { Ibid } 87 .\end{array}$

111 See, eg, Statement by the Treasurer (Paul Keating), 'Further Foreign Investment Liberalisation' (28 July 1986), document 15:31 in Snape, Gropp and Luttrell, above n 54, 724; Statement by the Minister Assisting the Treasurer (C Hurford), 'Foreign Investment Guidelines Eased' (29 October 1985), document 15:30 in Snape, Gropp and Luttrell, above n 54, 722.

112 See Table 1.1 above.

113 Snape, Gropp and Luttrell, above n 54, 456.

114 Address by the Minister for Foreign Affairs and Trade (Senator Evans)

(7 February 1990), document 10:24 in Snape, Gropp and Luttrell, above n 54.

115 See Table 1.1 above.

116 See generally Standing Committee on Foreign Affairs, Defence and Trade, Senate, Parliament of Australia, Australia and Latin America (June 1992).

117 See JSCOT, Report 4: Treaties Tabled on 15 and 29 October 1996 (November 1996) [1.56], [1.65]. 
into treaties with particular partners can be identified, no single public narrative explains the range of new BIT partners during this period. In the mid-1990s Australia also entered negotiations with major emerging economies including Russia, India, Brazil, and South Africa, without concluding BITs with those countries. ${ }^{118}$

Australia's BITs were generally seen as protecting its outbound investors when they entered foreign markets, particularly developing countries or economies in transition. Negotiators appear to give only limited consideration to the possibility that these agreements could be used by foreign investors entering Australia to challenge regulatory actions. For example, in its report on the Chile and Peru BITs, JSCOT found 'little evidence' of Chilean or Peruvian investment in Australia at the time. ${ }^{119}$ Thus, although the obligations contained in the BITs are reciprocal and almost all contain ISDS mechanisms, ${ }^{120}$ Australia thought it 'highly unlikely' that it would ever be required to pay compensation for expropriation or other harm to a foreign investor. ${ }^{121}$ Moreover, these BITs closely followed the Australian model agreement, hence reflecting its interests and agenda. ${ }^{122}$ As a result, these BITs were generally signed and ratified with no serious concerns being raised.

This apparently limited foresight about the potentially far-reaching implications of investment obligations, particularly through ISDS (as we discuss in Chapters 2 and 5), mirrors the experiences identified in other countries, both developed and developing, as noted above. In Australia, the negotiations for the MAI did provoke discussion of how the agreement could intrude on Australia's sovereignty and regulatory space. Some of these concerns related to particular proposals for the content of the MAI, which might bind state governments as well as the federal government, or require the removal of screening processes for foreign investment. $^{123}$ In addition to these specific concerns noted by the government, some commentators raised wider arguments about the

118 Foreign Investment Review Board, Annual Report 1994-1995 (Australian Government Publishing Service, 1996) 8.

119 See JSCOT, Report 4, above n 117, [1.56], [1.65].

120 See Chapter 5.

121 See DFAT, Government of Australia, Agreement between Australia and Uruguay on the Promotion and Protection of Investments: National Interest Analysis (tabled 12 March 2002); DFAT, Government of Australia, Agreement between Australia and Egypt on the Promotion and Protection of Investments: National Interest Analysis (tabled 12 March 2002).

122 See JSCOT, Report 4, above n 117, [1.55], [1.63].

123 Foreign Investment Review Board, Annual Report 1995-1996 (Australian Government Publishing Service, 1997) 8. 
potential for investment protections in the MAI to narrow the policy space available to regulators in the future. ${ }^{124}$ One point of particular concern was the nature of the country-specific exceptions provided in the agreement, which shielded only pre-existing measures or policies, precluding more restrictive future policies. ${ }^{125}$ In addition, some regarded the definition of expropriation as too broad, covering a wide range of measures not directly related to foreign investment and placing foreign investors in a position superior to that of Australian companies. ${ }^{126}$

The greater concerns expressed about the MAI, compared to Australia's BITs, may be explained by a few factors. First, due to the size of the MAI and the nature of the parties involved (including the US and the EU), Australia would have been more likely to be affected by the agreement as a recipient of investment (rather than as a source of outward investment). Second, when Australia started to conclude its BITs in the late 1980s, very few known ISDS cases existed. By the time the MAI was being negotiated in the late 1990s, more cases had arisen, along with a general unease about the effects of globalisation and international economic law, as we now discuss.

\section{SECOND GENERATION: THE SHIFT TOWARDS PTAs}

The conclusion of a PTA with Singapore in 2003 (SAFTA) marked an important turning point for Australia's international economic diplomacy. The government still made clear statements in favour of multilateralism as a tool for reducing trade barriers, but it had shifted towards viewing bilateral or regional PTAs as stepping stones towards this goal, rather than as antagonistic competitors with it. ${ }^{127}$ In addition to the SAFTA, Australia concluded another four PTAs by the end of 2009, with the US, Thailand, Chile, and ASEAN (alongside New Zealand), as set out in Table 1.2.

\footnotetext{
124 JSCOT, Report 18, above n 102, [6.10]-[6.16].

125 Ibid [4.23]-[4.25], [6.34]-[6.62].

126 Ibid [6.63]-[6.76].

127 DFAT, Advancing the National Interest: Australia's Foreign and Trade Policy White Paper (Commonwealth of Australia, 2003) 49, 58-63; Statement of Minister for Foreign Affairs, Alexander Downer MP, 'Trade Influences: Where Next?', Hayman Island (8 September 2002).
} 
Table 1.2 Australia's 'Second Generation' BITs and PTAs in Order of Signature

\begin{tabular}{ll}
\hline Year of signature & Agreement \\
\hline 2003 & SAFTA \\
2004 & AUSFTA \\
2004 & TAFTA \\
2005 & Australia-Turkey BIT \\
2005 & Australia-Mexico BIT \\
2008 & ACIFTA \\
2009 & AANZFTA \\
\hline
\end{tabular}

Australia's move towards actively pursuing PTAs arose, in part, from the slow progress of multilateral negotiations in the WTO. ${ }^{128}$ Progress at the multilateral level had been slowed by several factors: significant opposition to trade liberalisation (including major protests at WTO negotiating rounds, such as the Ministerial Conference held in Seattle in 1999);129 intractable differences on issues such as agriculture, making it difficult for the WTO Members to move forward using the 'single undertaking' model according to which "nothing is agreed until everything is agreed'; 130 and the expanded and diversified WTO membership. Not only were multilateral talks beginning to stall, but Australia was also afraid of being left behind or disadvantaged by other countries' bilateral trade arrangements. ${ }^{131}$ In addition to these external factors, domestic politics also played a role. When Prime Minister John Howard and the Coalition came to power in 1996, part of their campaign platform had been to pursue bilateral negotiations as a means of accessing export markets. ${ }^{132}$ Thus, the 1997 White Paper 'In the National Interest' demonstrated a greater appetite for bilateral and regional trade negotiations, which could be 'the course that will bring Australia the most substantial gains in market access in the shortest time frame'. ${ }^{133}$

This context for Australia's embracing of bilateralism is important because it influenced the content of its negotiated agreements. PTAs were

\footnotetext{
128 See Capling, Australia and Trade, above n 54, ch 8.

129 Ibid.

130 Statement of Minister for Foreign Affairs, above n 127.

131 See, eg, JSCOT, Report 102: Treaties Tabled on 12 and 16 March 2009 (June 2009) [2.13]-[2.14].

132 Capling, Australia and Trade, above n 54, 171.

133 DFAT, In the National Interest (1997) 42.
} 
viewed as a tool for achieving liberalisation that had not yet been secured through the WTO framework: 'WTO-plus' obligations. Many of the commitments made in these PTAs took further steps in areas already covered by WTO rules, such as eliminating remaining barriers to trade in goods (tariffs and quantitative restrictions), liberalising additional services sectors, and (as discussed further in Chapter 2) increasing minimum standards of intellectual property protection. For Australia, one particular area of concern that motivated bilateral negotiations was the reduction of tariffs and quantitative restrictions that limited access for its agricultural goods in other markets, such as the quantitative restrictions imposed by the US on beef and sugar imports. ${ }^{134}$ In addition to 'WTO-plus' obligations, whole new disciplines were included in some of the PTAs concluded in this era, covering topics such as e-commerce, ${ }^{135}$ competition policy, ${ }^{136}$ environment ${ }^{137}$ (discussed further in Chapter 6), and labour. ${ }^{138}$ Through the inclusion of chapters for the protection of foreign investors, ${ }^{139}$ Australia began to incorporate obligations usually found in BITs into its PTAs: a significant contrast to the first generation of agreements, in which trade and investment were kept separate. The increasingly broad subject matter of PTAs creates further potential for these agreements to erode regulatory sovereignty, as we discuss in later chapters.

During this period, there was generally bipartisan support for entry into PTAs, although the AUSFTA was an exception. ${ }^{140}$ Yet even where the treaties received broad support, they were not without controversy,

134 Very little was actually achieved on these two points in the final agreement. See Capling, All the Way, above n 7, 66-69; Andrew D Mitchell, 'The Australia-United States Free Trade Agreement' in Ross P Buckley, Vai Io Lo and Laurence Boulle (eds), Challenges to Multilateral Trade: The Impact of Bilateral, Preferential and Regional Agreements (Kluwer Law International, 2008).

135 See, eg, ACIFTA ch 16.

136 See, eg, TAFTA ch 12.

137 See, eg, AUSFTA ch 19.

138 See, eg, AUSFTA ch 18.

139 See, eg, SAFTA ch 8.

140 The political rifts regarding this agreement are revealed by the two Parliamentary committee reports on the agreement. See JSCOT, Report 61: The Australia-United States Free Trade Agreement (June 2004); Parliament of Australia, Senate Select Committee Australia United States Free Trade Agreement, Final Report (August 2004). See also Bryan Mercurio, 'Should Australia Continue Negotiating Bilateral Free Trade Agreements? A Practical Analysis' (2004) 27 University of New South Wales Law Journal 667, 668. 
reflecting the heightened public awareness of the potential impact of globalisation and international economic law on other policy areas, such as the protection of public health and the natural environment.

Concerns about the impact of the agreement on Australia's sovereignty were raised during the JSCOT process for the SAFTA, with some submissions to the inquiry noting that the agreement may "limit the future actions of Australian governments' ${ }^{141}$ Of particular concern was the 'negative list' approach to coverage of the services obligations of the agreement, which meant that activities were covered unless they were specifically carved out. ${ }^{142}$ JSCOT responded to these concerns regarding regulatory autonomy, noting that ' $[\mathrm{t}] \mathrm{he}$ Committee does not agree that FTAs impose limitations on sovereignty-they are, in fact, instances of the exercise of sovereignty'. ${ }^{143}$ Moreover, the JSCOT report noted that if such problems were to arise, the agreement could be amended or terminated in the future, as well as the biennial review process allowing governments to add sectors to their list of reservations if necessary. ${ }^{144}$ Finally, the JSCOT process considered the possibility, raised by some critics of the agreement, that the investment provisions could expose Australia to claims similar to those the US and Canada had experienced under the NAFTA. ${ }^{145}$ In response to these concerns, DFAT provided a detailed analysis of how the ISDS provisions of the SAFTA differed from those of the NAFTA. ${ }^{146}$

Civil society wariness of PTAs and concern about regulatory autonomy varied greatly in relation to the five different trade agreements Australia concluded in this second generation. Although some issues were raised in relation to the first of these agreements (SAFTA), very little was said in relation to the last agreement, the 2009 AANZFTA. ${ }^{147}$ In fact, the JSCOT report for that agreement noted the absence of provisions requiring the parties to promote human rights, high labour standards or environmental protection, expressing no concern that other provisions of the agreement might adversely impact the policy space available to Australia or other governments. ${ }^{148}$ In contrast to the somewhat detailed discussion of ISDS

\footnotetext{
141 JSCOT, Report 52: Treaties Tabled in March 2003 (June 2003) [2.175].

142 See Chapter 3.

143 JSCOT, Report 52, above n 141, [2.176].

144 Ibid [2.176]-[2.177].

145 Ibid [2.107].

146 Ibid. See also DFAT, 'SAFTA-Response to Query from the Joint Standing Committee on Treaties, 19 June 2003'.

147 See JSCOT, Report 102, above n 131, ch 2.

148 Ibid [2.57]-[2.61].
} 
provisions undertaken in relation to the SAFTA, the JSCOT report on the ACIFTA, concluded five years later, referred to only one submission raising concerns about ISDS and its potential impact on health and environmental policy. ${ }^{149}$ This discrepancy suggests that civil society concern about regulatory autonomy is sensitive to the specific context of each agreement, including the identity of the parties and the scope of the obligations.

The most controversial and influential PTA Australia entered into during this period was the AUSFTA. ${ }^{150}$ As noted earlier, some commentators and community groups viewed several aspects of this agreement as threats to Australia's regulatory autonomy. These included provisions that would require specific alterations to Australia's existing laws, such as intellectual property protections or the process for listing pharmaceuticals on the PBS, ${ }^{151}$ as well as more general concerns that investment protection norms may undermine national sovereignty. ${ }^{152}$ In what was, at the time, a unique move for a developed country, Australia responded to these concerns by pushing for ISDS not to be included in the PTA. ${ }^{153}$ Australia succeeded in this regard, making this agreement a rare example of a US PTA with investment obligations but no ISDS.

The second generation of Australia's modern trade and investment agreements was dominated by PTAs, but two final BITs were also concluded in this period. ${ }^{154}$ Australia's BITs with Mexico and Turkey were both concluded in 2005. However, although they came after PTAs such as SAFTA and AUSFTA, they were based on the earlier Australian model BIT and their text is similar to that of first generation BITs. ${ }^{155}$ Although, in terms of chronology, they appear in the second generation of Australia's agreements, these two BITs are perhaps better viewed as late examples of the first generation. Negotiations for the Turkey BIT

149 JSCOT, Report 95: Treaties Tabled on 4 June, 17 June, 25 June and 26 August 2008 (October 2008) [3.52].

150 On the controversies surrounding the agreement, see generally Linda Weiss, Elizabeth Thurbon and John A Mathews, How to Kill a Country: Australia's Devastating Trade Deal with the United States (Allen \& Unwin, 2004); Capling, All the Way, above n 7; Burrell and Weatherall, above n 5; Mitchell, above n 134.

151 Capling, All the Way, above n 7, 59-65.

152 JSCOT, Report 61, above n 140, [12.18], [12.22]-[12.25].

153 Instead, the parties to AUSFTA merely agreed to the possibility of future consultations on ISDS. See AUSFTA art 11.16.

154 See Table 1.2 above.

155 JSCOT, Report 72: Treaties Tabled on 29 November 2005 (2) (February 2006) [5.12]. 
began in 1999, ${ }^{156}$ while the Mexico BIT built on a general trade and investment agreement concluded in 1997. ${ }^{157}$ Yet, the general concerns that had arisen regarding regulatory autonomy were reflected in the review of the Mexico BIT. Perhaps informed by Mexico's own experience with ISDS cases under the NAFTA, ${ }^{158}$ the Queensland government expressed concerns that the BIT might require Australian governments to pay compensation for actions consistent with domestic law, such as the revocation of a licence or approval. ${ }^{159}$ In response to these concerns:

DFAT advised that it was unlikely that regulatory action by States, such as the imposition of taxation or the lawful revocation of licences or permits, would constitute expropriation at international law. ${ }^{160}$

Although this interaction was not a full or thorough discussion of the potential risks to regulatory autonomy posed by BITs or IIAs, the fact that these questions were even raised in relation to the Mexico BIT, when they had not been raised in relation to Australia's 19 previous BITs, demonstrates the increase in concern about regulatory autonomy that characterised the second generation of Australia's trade and investment agreements.

\section{THIRD GENERATION: BACKLASH AND '21ST CENTURY PTAs'}

Concerns about the impact of PTAs on Australia's regulatory autonomy have escalated in recent years, in the wake of disputes brought against it and other developed countries relating to health and environmental

156 Ibid [5.2].

157 Trade and Investment Agreement between the Government of Australia and the Government of the United Mexican States, signed 13 November 1994, [1997] ATS 15 (entered into force 3 April 1997).

158 Mexico was a respondent in notable cases relating to licences and approvals. See, eg, Metalclad v Mexico, Award; Tecmed v Mexico, Award.

159 JSCOT, Report 83: Treaties Tabled on 20 June (2), 17 October, 28 November (2) 2006 and $\mathrm{CO}_{2}$ Sequestration in Sub-Seabed Formations (February 2007) [2.13].

160 Ibid [2.14]. 
policies. ${ }^{161}$ In 2010, the Australian Productivity Commission issued a report on bilateral and regional trade agreements, which also considered the investment aspects of these agreements. ${ }^{162}$ The Productivity Commission is an independent authority established by Commonwealth statute, which provides research and advice to governments on a range of policy issues, either at the request of a Minister or on its own initiative. ${ }^{163}$ The Commission's 2010 Report was prepared because:

The Commission was asked by the Government to examine the effects of such agreements on a range of matters, including trade and investment barriers, prospects for multilateral reform, regional integration and Australia's economy generally. ${ }^{164}$

Among many other findings, the Commission's Report gave the following advice related to regulatory autonomy:

The Australian Government should not include matters in bilateral and regional trade agreements that would serve to increase barriers to trade, raise costs or affect established social policies without a comprehensive review of the implications and available options for change. ${ }^{165}$

Further, the Commission made specific recommendations about the process of ISDS, suggesting that the government should 'seek to avoid the inclusion of investor-state dispute settlement provisions in [PTAs] that grant foreign investors in Australia substantive or procedural rights greater than those enjoyed by Australian investors' ${ }^{166}$ Not long after the release of this report, the first ever ISDS case against Australia was launched by Philip Morris, challenging the consistency of cigarette plain-packaging requirements with the 1993 Australia-Hong Kong BIT, as discussed further in Chapter 2. That agreement was one of Australia's first generation BITs, concluded before many ISDS cases had been brought and concerns about their potential impact on 'regulatory

161 See, eg, the tobacco-related disputes discussed in Chapter 2; Appellate Body Report, US-Clove Cigarettes; Appellate Body Reports, EC-Seal Products; Appellate Body Report, US-Tuna II (Mexico); Vattenfall v Germany, Notice of Arbitration.

162 Productivity Commission, Australian Government, Bilateral and Regional Trade Agreements: Productivity Commission Research Report (November 2010) ('Productivity Commission Report').

163 Productivity Commission Act 1998 (Cth) s 6(1).

164 Productivity Commission Report, above n 162, iii.

165 Ibid recommendation 4.

166 Ibid recommendation 4(b). 
autonomy' had begun to develop. ${ }^{167}$ In December 2015, Philip Morris' claim was dismissed on jurisdictional grounds, ${ }^{168}$ but the litigation has still had a significant impact on the third generation of Australia's PTAs. The Productivity Commission Report, along with the Philip Morris arbitration, contributed to ISDS becoming a focal point for concerns regarding regulatory autonomy and PTAs in Australia.

Initially, the government endorsed the Productivity Commission's recommendation that ISDS provisions not be included in future PTAs, through the Gillard Trade Policy Statement of April 2011.169 This policy changed when the Liberal-National Coalition was elected in September 2013. Since that time, the inclusion of ISDS provisions in PTAs has been considered on a case-by-case basis. ${ }^{170}$ Outside the major political parties there has been even stronger opposition to ISDS, with Australian Greens' Senator Peter Whish-Wilson introducing a private Senator's Bill in 2014 that would prevent the government concluding any future treaties that included an ISDS mechanism. ${ }^{171}$ Although the Bill was never voted on, its discussion by Senate Foreign Affairs, Defence and Trade Legislation Committee provides further insight into the views of Australia's political parties on ISDS. The Coalition members maintained that ISDS may be a worthwhile inclusion in some agreements. ${ }^{172}$ The Labor Party Senators on the Committee felt that ISDS was 'unnecessary', but that it was also 'not desirable to radically constrain'

167 For further detail on the frequency of disputes initiated under ISDS mechanisms, see UNCTAD, World Investment Report 2015: Reforming International Investment Governance (United Nations, 2015) 114.

168 See Philip Morris v Australia, Jurisdictional Decision.

169 DFAT, Gillard Government Trade Policy Statement: Trading Our Way to More Jobs and Prosperity (April 2011) 14.

170 Parliament of Australia, Senate Foreign Affairs, Defence and Trade Legislation Committee, Trade and Foreign Investment (Protecting the Public Interest) Bill 2014 (August 2014) [2.7].

171 See Trade and Foreign Investment (Protecting the Public Interest) Bill 2014 (Cth); Explanatory Memorandum Trade and Foreign Investment (Protecting the Public Interest) Bill 2014 (Cth).

172 Parliament of Australia, Senate Foreign Affairs, Defence and Trade Legislation Committee, Trade and Foreign Investment (Protecting the Public Interest) Bill 2014 (August 2014) 17. 
the government's treaty making power through the proposed legislation. ${ }^{173}$ The majority of the Committee suggested that concerns regarding ISDS would be better addressed through careful treaty drafting and the inclusion of appropriate safeguards. ${ }^{174}$

Another focal point of concern and backlash regarding PTAs in this third generation of Australia's agreements has been the process of treaty negotiation. In June 2015, the Senate Foreign Affairs, Defence and Trade References Committee released a report titled 'Blind Agreement', discussing the need for greater transparency and consultation in the making of treaties. ${ }^{175}$ The report was not limited to discussion of trade and investment agreements, applying more broadly to Australia's treaty making process. However, negotiation of the ChAFTA and TPP were cited by the Committee as important context for its inquiry. ${ }^{176}$ The majority of the Committee recommended, inter alia, that parliamentarians and their advisors and non-governmental stakeholders be given greater opportunity to consult on the negotiation of treaties, and to review and comment on the text of treaties before their signature. As well as confidentiality of negotiations being unenforceable in a digital age, ${ }^{177}$ the Committee noted evidence that international trade agreements can sometimes have unintended consequences, especially with regard to intellectual property provisions negotiated in the context of bilateral or regional trade deals'. ${ }^{178}$ These and other factors suggested to the majority of the Committee that treaty-making processes in Australia required reform, because 'the context of treaty making - particularly in relation to trade treaties - had changed dramatically in recent decades'. ${ }^{179}$ The Coalition government disagreed with all of the Committee's findings, creating doubt as to whether or not Australia's treaty process will be reformed to allow for greater involvement of parliamentarians or the community. ${ }^{180}$

\footnotetext{
173 Ibid 19-21.

174 Ibid 17.

175 Parliament of Australia, Senate Foreign Affairs, Defence and Trade References Committee, Blind Agreement: Reforming Australia's Treaty-Making Process (June 2015).

176 Ibid ix, [2.27]-[2.34].

177 Ibid [2.35]-[2.36].

178 Ibid [2.33].

179 Ibid [3.46].

180 See ibid, Dissenting Report by Coalition Senators; Australian Government, Australian Government Response to the Senate Foreign Affairs, Defence and Trade References Committee Report: Blind Agreement: Reforming Australia's Treaty-Making Process (February 2016).
} 
Since 2010, Australia has concluded four new PTAs, including with three of Australia's largest trading partners in North Asia (Korea, Japan and China), as well as an Investment Protocol to the ANZCERTA, as set out in Table 1.3. In 2016, Singapore and Australia agreed significant amendments to the SAFTA, aligning that agreement more closely with Australia's recent PTA practice.

\section{Table 1.3 Australia's 'Third Generation' BITs and PTAs in Order of Signature}

\begin{tabular}{ll}
\hline Year of signature & Agreement \\
\hline 2011 & ANZCERTA Investment Protocol \\
2012 & MAFTA \\
2014 & KAFTA \\
2014 & JAEPA \\
2015 & ChAFTA \\
2016 & TPP \\
\hline
\end{tabular}

Despite the Productivity Commission report and the Philip Morris arbitration, two of these PTAs-KAFTA and ChAFTA—include ISDS mechanisms. ${ }^{181}$ The Coalition government has emphasised the economic benefits of these treaties, while also noting that they include adequate safeguards to protect Australia's ability to regulate in the public interest. ${ }^{182}$ In this third generation of PTAs, the drafting of investment obligations has evolved considerably when compared to the first generation of Australia's BITs, ${ }^{183}$ while the ChAFTA ISDS provisions include a novel mechanism for the resolution of disputes regarding 'public welfare measures', as elaborated in Chapter 5. As a result of ongoing concerns about regulatory autonomy, many of these agreements include general exceptions clauses that apply to investment obligations, ${ }^{184}$ as well as clarifications of the scope of concepts such as indirect expropriation and fair and equitable treatment, ${ }^{185}$ as detailed in Chapter 4.

\footnotetext{
181 ChAFTA art 9.12; KAFTA art 11.16. However, as discussed in greater detail in Chapter 5, the ChAFTA mechanism is limited in scope.

182 See, eg, Regulation Impact Statement, KAFTA (4 February 2013) [72]-

[74]; Regulation Impact Statement, ChAFTA (23 March 2015) [152].

183 These drafting changes are discussed in Chapter 4.

184 See, eg, MAFTA art 12.18.

185 See, eg, KAFTA annex 11-B and art 11.5.2(a).
} 
In addition to the four PTAs that have entered into force, a number of other third generation PTAs are being negotiated or have recently been finalised. Most notable among these is the TPP, which was signed in February 2016 by 12 nations accounting for over 35 per cent of world GDP. ${ }^{186}$ As well as being significant simply for its size, the TPP is noteworthy as an example of a '21st century' trade agreement, which seeks to include innovative provisions that achieve further liberalisation than that achieved in earlier PTAs. For example, the TPP includes chapters relating to regulatory coherence, small and medium-sized businesses, and State-owned enterprises, ${ }^{187}$ as well as novel environmental provisions covering fisheries subsidies and other disciplines not often included in PTAs. ${ }^{188}$ These new provisions demonstrate a tension inherent in the TPP and other contemporary PTAs, between recognising the parties' 'inherent right to regulate' and 'safeguard public welfare', ${ }^{189}$ and their desire to pursue deeper economic integration and expand the reach of PTAs. ${ }^{190}$ The TPP also exemplifies the impact of tobacco-related disputes on subsequent negotiations, as the agreement includes a special carve-out from ISDS for tobacco control measures. ${ }^{191}$ A similar clause was also included in the 2016 agreement to amend SAFTA, signalling that Australia may seek to include this provision in future agreements. ${ }^{192}$

The TPP was signed by the 12 negotiating parties, but it cannot enter into force in its current form absent some unexpected developments in the US. After President Trump took office in the US in January 2017, one of his first executive acts was to withdraw the US from the TPP. ${ }^{193}$ Under the terms of the TPP, the treaty can enter into force only if at least six of its original signatories complete their applicable legal requirements to ratify it, provided that those parties represent at least 85 per cent of the combined gross domestic product of the 12 original signatories (based on

186 DFAT, TPP, <http://dfat.gov.au/trade/agreements/tpp/pages/trans-pacificpartnership-agreement-tpp.aspx $>$ (last visited 7 April 2017).

187 TPP ch 17, 24, 25.

188 TPP ch 20 art 20.16.

189 TPP preamble.

190 For a discussion of these tensions in relation to regulatory coherence provisions, see Elizabeth Sheargold and Andrew D Mitchell, 'The TPP and Good Regulatory Practices: An Opportunity for Regulatory Coherence to Promote Regulatory Autonomy?' (2016) 15 World Trade Review 587.

191 The mechanism is a denial of benefits clause, which TPP parties may elect to use. See TPP art 29.5 and discussion in Chapter 5 of this volume.

192 SAFTA 2016 ch 8 art 22. See also Chapter 5 of this volume.

193 Letter from Maria L Pagan, Acting USTR, to the Trans-Pacific Partnership Depositary (30 January 2017). 
2013 figures). ${ }^{194}$ This requirement means that the TPP cannot enter into force without the US (and Japan), because it would be impossible for the other parties to reach the 85 per cent threshold. However, this does not necessarily mean that the agreement is dead. The remaining 11 TPP signatories may negotiate a new means of entry into force for the agreement as among themselves, or the agreement may be used as a template for future agreements between these and other parties.

The negotiation of the TPP sparked a new wave of concern among civil society about the impact of the agreement on regulatory autonomy, particularly in relation to IP protections and ISDS. ${ }^{195}$ Unlike previous JSCOT reports, which had downplayed the risk of ISDS cases being brought against Australia, the report on the TPP suggested that the Australian government 'be open about the prospect that ISDS cases may be brought against it'. ${ }^{196}$ In responding to concerns regarding the potential impact of the ISDS provisions in the TPP on regulatory autonomy, the Committee noted that the benefits of ISDS for Australian investors had been largely overlooked in the debate, ${ }^{197}$ and that the TPP ISDS mechanism included 'new qualifications and improvements' that 'will protect Australia public interest regulation from claims'. ${ }^{198}$ Although it acknowledged that investors may bring unmeritorious cases, the Committee considered that 'should a case be brought against Australia in relation to public interest regulation under the TPP ISDS provisions it would most likely fail'. ${ }^{199}$ A majority of the Committee approved these findings. ${ }^{200}$

The pursuit of PTAs retains support, even though their potential risks (especially through ISDS) for regulatory autonomy are now well known and understood by the Australian government. Aside from the small period when the Gillard government stated that it would not include ISDS mechanisms in future treaties, Australia's response to increased concerns regarding regulatory autonomy has been to make small but significant changes in the drafting of key disciplines, as will be demonstrated in more detail through the following chapters.

\footnotetext{
194 See TPP arts 30.5.1-30.5.3.

195 JSCOT, Report 165, above n 18, ch 6, 7.

196 Ibid [6.68]. See also [6.81].

197 Ibid [6.28], [6.73].

198 Ibid [6.79]. See also [6.34], [6.44].

199 Ibid [6.42].

200 The Australian Greens Party member of the committee released a dissenting report. See JSCOT ibid 196.
} 


\section{CONCLUSIONS AND OUTLINE}

Concerns regarding regulatory autonomy, as that concept is conceived today, were not a major influence or consideration in the conclusion of the first generation of Australia's BITs or the ANZCERTA. In these agreements, Australia was typically the larger and more developed economy. However, by the late 1990s, concerns about the impact of economic agreements on policy space in other areas, such as public health and environmental protection, had begun to emerge. This change coincided with Australia's shift in policy towards approving bilateral PTAs, in its second generation of agreements. Following the Productivity Commission Report in 2010 and the initiation of arbitration by Philip Morris against Australia, concerns about regulatory autonomy grew and have become a prominent feature of parliamentary and public consideration of Australia's PTAs. However, Australia has nevertheless continued to embrace these agreements. As we will demonstrate in the chapters that follow, these concerns have manifested in modifications to treaty drafting such as the addition of new safeguards to agreements, although the efficacy of these provisions is not always clear.

In the following chapters, we consider how the range of different BITs and PTAs that Australia has concluded since 1983 may influence the country's regulatory autonomy in three key areas: the protection of intellectual property, the regulation of services, and the protection of foreign investors. As foreshadowed in this introductory chapter, these three areas have often given rise to the greatest concerns about potential constraints on regulatory autonomy.

We begin in Chapter 2 with an analysis of intellectual property standards contained in Australia's PTAs, which have received considerable public attention, particularly in our PTAs negotiated with the US: the AUSFTA and TPP. Chapter 3 examines rules relating to trade in services, with a particular focus on how the structure of commitments through either a 'positive' or 'negative' list of commitments shapes the extent of both trade liberalisation and policy space. Given the particular prominence of concerns regarding the substance of protections for foreign investors and enforcement of those standards through ISDS, Chapters 4 and 5, respectively, are dedicated to these topics. To provide a more detailed illustration of how these disciplines may impact on domestic policy making, Chapter 6 considers the impact of Australia's PTAs and BITs on the ability to regulate for the protection of the environment. The chapter includes a detailed consideration of how investment standards may apply to a range of environmental measures, 
using cases that have been decided under the NAFTA, as well as considering Australian PTA exceptions and obligations that relate specifically to the environment.

This book does not suggest that regulatory autonomy is an absolute good, or that any limitations imposed by Australia's PTAs and BITs are negative from a policy perspective. As Associate Commissioner Andrew Stoler noted in his comments on the 2010 Productivity Commission Report, "there is reason to believe that a little bit of "regulatory chill" might be a good thing, even in Australia'. ${ }^{201}$ Similarly, Australia's Chief TPP Negotiator Elizabeth Ward stated before a JSCOT hearing in 2016 in relation to regulatory chill arising from ISDS: 'if it gives regulators en masse, including the public sector, pause for thought about the sort of legislation we are putting in place, that is no bad thing'. ${ }^{202}$ The very purpose of international economic law is to constrain States from enacting regulations that create barriers to trade or infringe on investor rights, in order to pursue the wider economic and welfare objectives underlying international trade law and international investment law.

Thus, the question we are examining in this book cannot be stated as simply as: do Australia's PTAs and BITs protect regulatory autonomy? Instead, the study we undertake in this book seeks to examine the extent to which Australia's PTAs and BITs constrain the ability of government to take legitimate regulatory actions in areas such as the protection of public health or the environment, and to examine alternative options for clarifying the scope of agreements or safeguarding regulatory space in areas where we believe it may be necessary. By examining all of Australia's PTAs and BITs, and, where relevant, making comparisons to other agreements, we hope to shed light on the overlapping web of agreements that currently shape not only Australia's regulatory autonomy but also Australia's gains from liberalisation of trade and the promotion and protection of inward and outward foreign investment. Changing patterns of Australia's treaty drafting over time reveal the complexity and nuance of the relationship between international economic law and regulatory autonomy, which is relevant to Australia and countries around the world as they face the ongoing challenges of globalisation.

201 Productivity Commission Report, above n 162, iii.

202 Evidence to JSCOT, Canberra (7 November 2016) 1 (Elizabeth Ward, Chief Negotiator, TPP, DFAT). 